\title{
Anti-A $\beta$ antibody target engagement: A response to Siemers et al.
}

Andrew D. Watt, ${ }^{123}$ Gabriela A. N. Crespi, ${ }^{7}$ Russell A. Down, ${ }^{123}$ David B. Ascher, ${ }^{7}$ Adam Gunn, ${ }^{13}$ Keyla A. Perez, ${ }^{13}$ Catriona A. McLean, ${ }^{18}$ Victor L. Villemagne, ${ }^{169}$ Michael W. Parker, ${ }^{47}$ Kevin J. Barnham ${ }^{135 *}$ and Luke A. Miles ${ }^{47 *}$

${ }^{1}$ Florey Institute of Neuroscience and Mental Health, ${ }^{2}$ Department of Pathology, ${ }^{3}$ Neuroproteomics Platform, Bio21 Molecular Science and Biotechnology Institute, ${ }^{4}$ Department of Biochemistry and Molecular Biology, ${ }^{5}$ Department of Pharmacology and Therapeutics, ${ }^{6}$ Department of Medicine, The University of Melbourne, Parkville, Melbourne, Victoria 3010, Australia, ${ }^{7}$ ACRF Rational Drug Discovery Centre and Biota Structural Biology Laboratory, St. Vincent's Institute of Medical Research, Fitzroy, Victoria 3056, Australia, ${ }^{8}$ Department of Anatomical Pathology, The Alfred Hospital, Victoria 3084, Australia, ${ }^{9}$ Department of Nuclear Medicine and Centre for PET, Austin Health, Heidelberg Victoria 3084, Australia

* These authors contributed equally to this work; corresponding authors:

Kevin Barnham kbarnham@unimelb.edu.au

Luke Miles Imiles@svi.edu.au 
We have read with interest the commentary by Siemers et al. regarding our paper describing the ability of the three anti-A $\beta$ antibodies, bapineuzumab, crenezumab and solanezumab to engage $A \beta$ in both a synthetic and a biological setting [28]. We appreciate the opportunity to clarify any misunderstandings and here provide a brief response to their concerns.

Siemers et al. begin their commentary by stating that our findings led to the conclusion "that all three antibodies failed to engage the intended molecular targets." This statement is wrong; as clearly stated in the abstract of our paper, "Bapineuzumab demonstrated target engagement with brain A $\beta$, consistent with published clinical data" [28]. To reiterate, we reported data showing that bapineuzumab was capable of binding soluble $A \beta$ with a low nanomolar affinity and demonstrated that the antibody could detect $\mathrm{A} \beta$ species in buffer and in brain homogenate and plasma from transgenic animal models of AD. Furthermore, in agreement with the Phase 3 clinical data [23], we demonstrated target engagement for bapineuzumab, where its target is brain-derived amyloid- $\beta$ peptides associated with Alzheimer's pathology (see, Figure 3a [28]). Our data also showed that neither solanezumab nor crenezumab effectively engaged this pool of $A \beta$, again consistent with the publicallyavailable clinical data $[9,10]$.

The first point raised by Siemers et al., is that the surface enhanced laser desorption/ionization time-of-flight mass spectrometry (SELDI-TOF MS) "does not possess a dynamic range sufficient to measure endogenous $A \beta$ peptides in murine and human plasma." This is incorrect. One of our investigations involved spiking diluted and denatured $\mathrm{AD}$-affected plasma samples with $\mathrm{A} \beta_{-42}$ at equivalent levels to the $\mathrm{A} \beta$ levels reported in $\mathrm{AD}$ plasma $[19,21]$. The resulting $A \beta$ was clearly observable using this technique; however, no $A \beta$ was observable in the non-spiked plasma. SELDI-TOF MS utilises antibody-based immunocapture coupled with the mass spectrometric detection of bound analytes. The advantages of MS-based systems are greater sensitivity and the ability to differentiate specific from nonspecific interactions based on the molecular weight of the captured species. More specifically, SELDI-TOF MS is capable of binding soluble $A \beta$ peptides at low femtomolar concentrations [4] and is able to resolve individual isoforms of $A \beta$ Any issues with dynamic range are more likely to be an issue at higher concentrations where saturation of the antibody occurs. 
Furthermore and consistent with our SELDI-TOF MS findings, analysis of the AD plasma proteome with the three antibodies using LC-MS/MS on a LTQ Orbitrap Elite also failed to detect any $A \beta$ This high resolution system has previously been used to characterise $A \beta$ in biological matrices, both qualitatively and quantitatively, [13] at levels consistent with those observed in AD-affected plasma [21,12]. The results of this analysis were wholly consistent with the SELDI-TOF MS experiments.

The possible explanations for the lack of observable Aßin AD-affected plasma include:

1. The $A \beta$ is bound in higher molecular weight complexes with other plasma proteins. It should be noted that such interactions would also affect the signal observed in plasma from transgenic animal models of $\mathrm{AD}$ in addition to ELISA-based measures of $\mathrm{A} \beta$ in human samples.

2. The $A \beta$ partitions into another blood fraction, as previously reported [26].

3. The Aßlevels as described by ELISA-based methodologies are overstated.

In their second point, Siemers et al., assert that the human brain homogenates utilised in our study "were prepared under conditions that yielded primarily aggregated/oligomer $A \beta$, a structural form of $A \beta$ to which solanezumab does not bind." The preparation of the cortical homogenates in our investigation was kept purposefully minimalistic in an effort to reduce the induction of aggregates and other artefacts. We utilised detergents and denaturants that have previously been shown to have no effect on $A \beta$ aggregation rates [22] and not to stabilise $A \beta$ in solution [17]. However, our data clearly demonstrates that a subset of the observable $A \beta$ in these samples was part of larger $A \beta$ aggregates or oligomers, as shown by the N-terminally truncated $A \beta$ species captured by bapineuzumab, which binds $A \beta$ via the Nterminus [20,11]. Siemers et al. also noted that "solanezumab is selective for soluble monomeric forms of $A \beta$, the Watt et al. brain extraction experiments were not properly designed to detect target engagement for this antibody". From this statement, are we to believe that Siemers et al. consider the AD-affected brain homogenate to contain no soluble monomeric $A \beta$ ? The lack of observable signal in the spectra indicates that either there is no soluble monomeric $\mathrm{A} \beta$ in the $\mathrm{AD}$ brain homogenate or that solanezumab is failing to bind $\mathrm{A} \beta$ in these samples due to cross-reactivity with more abundant proteins, a well-established short-coming of antibodies raised against linear sequences, such as crenezumab and solanezumab $[2,3,16,14]$. To reiterate, this technology is capable of detecting $A \beta$ at femtomolar concentrations [4] and our previous work has demonstrated that the $A \beta$ levels 
observed in these cortical homogenates using SELDI-TOF MS significantly correlate with the levels of soluble $A \beta$ present in these samples [29]. We designed the experiments to perturb the AD-affected cortical tissue as little as possible, and under those conditions, solanezumab failed to effectively engage $A \beta$ (see Figures $3 \& 4$ [28]).

In their third comment, Siemers et al. state that our immunoprecipitation (IP) pull-down experiments presented "no negative control experiments." This statement is wrong. To mitigate the risk of "very high risk of unspecific binding to the beads used for immunoprecipitation" we performed IP experiments from plasma with Fab fragments from these antibodies, with the Fab derived from bapineuzumab and with the magnetic beads alone as negative controls (see final paragraph of Results [28]). Twelve of the proteins pulled down by solanezumab and crenezumab, but not bound by either bapineuzumab or the beads alone, proved to contain substantial sequence identity with the mid-region $\mathrm{A} \beta$ epitopes targeted by these antibodies. This highlighted the potential for cross-reactivity of these antibodies. The isolation of the interleukin-12 receptor protein was of particular interest given reports that modulation of this pathway alleviated cognitive symptoms in a number of $\mathrm{AD}$ models $[27,25]$.

In their concluding statement, Siemers et al. claim that the findings of our investigations were inconsistent with the wealth of published literature on the three antibodies; however, examination of the articles cited in their commentary reveals that our findings are largely consistent with the published literature. The paper by Legleiter et al. [18] reported that m266 was able to inhibit the formation of fibrils by synthetic $\mathrm{A} \beta$ whilst the articles by Seubert et al. [24] and Gelfanova et al. [15] reported that $\mathrm{m} 266$ readily bound $\mathrm{A} \beta$ in human cerebrospinal fluid (CSF), a biological medium that contains 10-fold more $A \beta$, but less than one-tenth of the total protein observed in human plasma. These findings were consistent with our analysis of synthetic A $\beta$ using both SPR and SELDI-TOF MS which demonstrated that solanezumab had a sub-nanomolar affinity for $A \beta$ in non-complex samples. Our findings also readily supported the studies by DeMattos et al. [7,8,5,6] and Bard et al. [1] who reported that solanezumab was readily able to bind $A \beta$ in the cortical tissue and plasma of transgenic mouse models of AD. Furthermore, our findings remain consistent with the outcomes of the two Phase III clinical trials demonstrating that solanezumab was unable to modulate cortical A $\beta$ levels, leading Doody et al. [9] to conclude that the "data from these two phase 3 solanezumab trials did not show efficacy of this monoclonal antibody." 
To summarise, the findings of our recent paper remain consistent with the publicallyavailable data generated by clinical trials investigating these three therapeutic antibodies. Bapineuzumab engages $\mathrm{A} \beta$ in $\mathrm{AD}$-affected cortical tissue and remains the only antibody to definitively demonstrate target engagement through the significant reduction of cortical $A \beta$ [23]. Clinical trials of bapineuzumab showed that if brain-derived $A \beta$ is engaged, downstream perturbations in CSF tau levels will also be engaged. Solanezumab has a subnanomolar affinity for soluble $\mathrm{A} \beta$, but has little-to-no effect on $\mathrm{AD}$ brain-derived $\mathrm{A} \beta$ [9]. Like solanezumab, crenezumab has low nanomolar affinity for $\mathrm{A} \beta$ in simple samples; however, it is unable to readily engage brain-derived $A \beta$, consistent with its recent failure in two Phase 2 clinical trials [10]. Our current findings coupled with the failure of these antibodies in their respective clinical trials indicates that a more thorough and open investigation of these therapeutic antibodies is warranted.

\section{Potential Conflicts of Interest}

None

\section{References}

1. Bard F, Barbour R, Cannon C, Carretto R, Fox M, Games D, Guido T, Hoenow K, Hu K, JohnsonWood K, Khan K, Kholodenko D, Lee C, Lee M, Motter R, Nguyen M, Reed A, Schenk D, Tang $P$, Vasquez N, Seubert P, Yednock T (2003) Epitope and isotype specificities of antibodies to beta -amyloid peptide for protection against Alzheimer's disease-like neuropathology. Proc Natl Acad Sci U S A 100 (4):2023-2028. doi:10.1073/pnas.0436286100

2. Berglund L, Andrade J, Odeberg J, Uhlén M (2008) The epitope space of the human proteome. Protein Sci 17 (4):606-613. doi:10.1110/ps.073347208

3. Bonnycastle LL, Mehroke JS, Rashed M, Gong X, Scott JK (1996) Probing the basis of antibody reactivity with a panel of constrained peptide libraries displayed by filamentous phage. $J$ Mol Biol 258 (5):747-762. doi:10.1006/jmbi.1996.0284

4. Bradbury L, LeBlanc J, McCarthy D (2004) ProteinChip ${ }^{\circledR}$ Array-Based Amyloid $\beta$ Assays. In: Fung E (ed) Protein Arrays, vol 264. Methods in Molecular Biology. Humana Press, pp 245-257. doi:10.1385/1-59259-759-9:245

5. DeMattos RB, Bales KR, Cummins DJ, Dodart JC, Paul SM, Holtzman DM (2001) Peripheral anti-A beta antibody alters CNS and plasma $A$ beta clearance and decreases brain $A$ beta burden in a mouse model of Alzheimer's disease. Proc Natl Acad Sci U S A 98 (15):8850-8855. doi:10.1073/pnas.151261398

6. DeMattos RB, Bales KR, Cummins DJ, Paul SM, Holtzman DM (2002) Brain to plasma amyloid-beta efflux: a measure of brain amyloid burden in a mouse model of Alzheimer's disease. Science 295 (5563):2264-2267. doi:10.1126/science.1067568 
7. DeMattos RB, Bales KR, Parsadanian M, O'Dell MA, Foss EM, Paul SM, Holtzman DM (2002) Plaque-associated disruption of CSF and plasma amyloid-beta (Abeta) equilibrium in a mouse model of Alzheimer's disease. J Neurochem 81 (2):229-236

8. DeMattos RB, O'Dell M A, Parsadanian M, Taylor JW, Harmony JA, Bales KR, Paul SM, Aronow BJ, Holtzman DM (2002) Clusterin promotes amyloid plaque formation and is critical for neuritic toxicity in a mouse model of Alzheimer's disease. Proc Natl Acad Sci U S A 99 (16):1084310848. doi:10.1073/pnas.162228299

9. Doody RS, Thomas RG, Farlow M, Iwatsubo T, Vellas B, Joffe S, Kieburtz K, Raman R, Sun X, Aisen PS, Siemers E, Liu-Seifert H, Mohs R (2014) Phase 3 Trials of Solanezumab for Mild-toModerate Alzheimer's Disease. N Engl J Med 370 (4):311-321. doi:doi:10.1056/NEJMoa1312889

10. Fagan T (2014) Crenezumab Disappoints in Phase 2, Researchers Remain Hopeful. AlzForum. http://www.alzforum.org/news/conference-coverage/crenezumab-disappoints-phase-2researchers-remain-hopeful.

11. Feinberg H, Saldanha JW, Diep L, Goel A, Widom A, Veldman GM, Weis WI, Schenk D, Basi GS (2014) Crystal structure reveals conservation of amyloid-beta conformation recognized by 3D6 following humanization to bapineuzumab. Alzheimers Res Ther 6 (3):31. doi:10.1186/alzrt261

12. Figurski MJ, Waligorska T, Toledo J, Vanderstichele H, Korecka M, Lee VM, Trojanowski JQ, Shaw LM (2012) Improved protocol for measurement of plasma beta-amyloid in longitudinal evaluation of Alzheimer's Disease Neuroimaging Initiative study patients. Alzheimers Dement 8 (4):250-260. doi:10.1016/j.jalz.2012.01.001

13. Ford MJ, Cantone JL, Polson C, Toyn JH, Meredith JE, Drexler DM (2008) Qualitative and quantitative characterization of the amyloid $\beta$ peptide $(A \beta)$ population in biological matrices using an immunoprecipitation-LC/MS assay. J Neurosci Methods 168 (2):465-474. doi:http://dx.doi.org/10.1016/i.jneumeth.2007.11.019

14. Gardberg A, Dice L, Pridgen K, Ko J, Patterson P, Ou S, Wetzel R, Dealwis C (2009) Structures of Abeta-related peptide--monoclonal antibody complexes. Biochemistry (Mosc) 48 (23):52105217. doi:10.1021/bi9001216

15. Gelfanova V, Higgs RE, Dean RA, Holtzman DM, Farlow MR, Siemers ER, Boodhoo A, Qian YW, He $X$, Jin Z, Fisher DL, Cox KL, Hale JE (2007) Quantitative analysis of amyloid-beta peptides in cerebrospinal fluid using immunoprecipitation and MALDI-Tof mass spectrometry. Brief Funct Genomic Proteomic 6 (2):149-158. doi:10.1093/bfgp/elm010

16. James LC, Roversi P, Tawfik DS (2003) Antibody multispecificity mediated by conformational diversity. Science 299 (5611):1362-1367. doi:10.1126/science.1079731

17. Kim JR, Muresan A, Lee KYC, Murphy RM (2004) Urea modulation of $\beta$-amyloid fibril growth: Experimental studies and kinetic models. Protein Sci 13 (11):2888-2898. doi:10.1110/ps.04847404

18. Legleiter J, Czilli DL, Gitter B, DeMattos RB, Holtzman DM, Kowalewski T (2004) Effect of Different Anti-A $\beta$ Antibodies on $A \beta$ Fibrillogenesis as Assessed by Atomic Force Microscopy. J Mol Biol 335 (4):997-1006. doi:http://dx.doi.org/10.1016/j.jmb.2003.11.019

19. Mehta PD, Pirttila T, Mehta SP, Sersen EA, Aisen PS, Wisniewski HM (2000) Plasma and cerebrospinal fluid levels of amyloid beta proteins 1-40 and 1-42 in Alzheimer disease. Arch Neurol 57 (1):100-105

20. Miles LA, Crespi GAN, Doughty L, Parker MW (2013) Bapineuzumab captures the N-terminus of the Alzheimer's disease amyloid-beta peptide in a helical conformation. Sci Rep 3. doi:http://www.nature.com/srep/2013/130218/srep01302/abs/srep01302.html\#supplemen tary-information

21. Roher AE, Esh CL, Kokjohn TA, Castano EM, Van Vickle GD, Kalback WM, Patton RL, Luehrs DC, Daugs ID, Kuo YM, Emmerling MR, Soares H, Quinn JF, Kaye J, Connor DJ, Silverberg NB, Adler CH, Seward JD, Beach TG, Sabbagh MN (2009) Amyloid beta peptides in human plasma 
and tissues and their significance for Alzheimer's disease. Alzheimers Dement 5 (1):18-29. doi:10.1016/j.jalz.2008.10.004

22. Ryan TM, Friedhuber A, Lind M, Howlett GJ, Masters C, Roberts BR (2012) Small amphipathic molecules modulate secondary structure and amyloid fibril-forming kinetics of Alzheimer disease peptide Abeta(1-42). J Biol Chem 287 (20):16947-16954. doi:10.1074/jbc.M111.321778

23. Salloway S, Sperling R, Fox NC, Blennow K, Klunk W, Raskind M, Sabbagh M, Honig LS, Porsteinsson AP, Ferris S, Reichert M, Ketter N, Nejadnik B, Guenzler V, Miloslavsky M, Wang D, Lu Y, Lull J, Tudor IC, Liu E, Grundman M, Yuen E, Black R, Brashear HR (2014) Two Phase 3 Trials of Bapineuzumab in Mild-to-Moderate Alzheimer's Disease. N Engl J Med 370 (4):322333. doi:doi:10.1056/NEJMoa1304839

24. Seubert P, Vigo-Pelfrey C, Esch F, Lee M, Dovey H, Davis D, Sinha S, Schlossmacher M, Whaley J, Swindlehurst C, et al. (1992) Isolation and quantification of soluble Alzheimer's beta-peptide from biological fluids. Nature 359 (6393):325-327. doi:10.1038/359325a0

25. Tan MS, Yu JT, Jiang T, Zhu XC, Guan HS, Tan L (2014) IL12/23 p40 inhibition ameliorates Alzheimer's disease-associated neuropathology and spatial memory in SAMP8 mice. J Alzheimers Dis 38 (3):633-646. doi:10.3233/jad-131148

26. Villemagne VL, Perez KA, Pike KE, Kok WM, Rowe CC, White AR, Bourgeat P, Salvado O, Bedo J, Hutton CA, Faux NG, Masters CL, Barnham KJ (2010) Blood Borne Amyloid-beta Dimer Correlates With Clinical Markers of Alzheimer's Disease. J Neurosci 30 (18):6315-6322

27. Vom Berg J, Prokop S, Miller KR, Obst J, Kalin RE, Lopategui-Cabezas I, Wegner A, Mair F, Schipke CG, Peters O, Winter Y, Becher B, Heppner FL (2012) Inhibition of IL-12/IL-23 signaling reduces Alzheimer's disease-like pathology and cognitive decline. Nat Med 18 (12):18121819. doi:10.1038/nm.2965

28. Watt A, Crespi GN, Down R, Ascher D, Gunn A, Perez K, McLean C, Villemagne V, Parker M, Barnham K, Miles L (2014) Do current therapeutic anti-A $\beta$ antibodies for Alzheimer's disease engage the target? Acta Neuropathol (Berl) 127 (6):803-810. doi:10.1007/s00401-014-12902

29. Watt AD, Perez KA, Rembach A, Sherrat NA, Hung LW, Johanssen T, McLean CA, Kok WM, Hutton CA, Fodero-Tavoletti M, Masters CL, Villemagne VL, Barnham KJ (2013) Oligomers, fact or artefact? SDS-PAGE induces dimerization of beta-amyloid in human brain samples. Acta Neuropathol 125 (4):549-564. doi:10.1007/s00401-013-1083-z 